\title{
Filling the Gap of Data-Limited Fish Species in the Eastern Mediterranean Sea: A Contribution by Citizen Science
}

\author{
Roxani Naasan Aga Spyridopoulou ${ }^{1, *}$, Joachim Langeneck ${ }^{2}$, Dimitris Bouziotis ${ }^{1}{ }^{(0}$, \\ Ioannis Giovos ${ }^{1,2,3}$, Periklis Kleitou 1,3 (D) and Stefanos Kalogirou $4, *$ (D) \\ 1 iSea, Environmental Organisation for the Preservation of the Aquatic Ecosystems, Ochi Av. 11, \\ 55438 Agios Paulos, Thessaloniki, Greece; dbouziotis@hotmail.com (D.B.); \\ ioannis.giovos@isea.com.gr (I.G.); pkleitou@merresearch.com (P.K.) \\ 2 Department of Biology, University of Pisa, via Derna 1, 56126 Pisa, Italy; jlangeneck@biologia.unipi.it \\ 3 Marine and Environmental Research (MER) Lab Ltd., 202 Amathountos Av., Marina Gardens, Block B, \\ Offices \# 13-14, Parekklisia, 4533 Limassol, Cyprus \\ 4 Hellenic Centre for Marine Research, Hydrobiological Station of Rhodes, 85100 Rhodes, Greece \\ * Correspondence: roxani.naasanaga@isea.com.gr (R.N.A.S.); stefanos.kalogirou@gmail.com (S.K.); \\ Tel.: +30-23-1309-0696 (R.N.A.S.); +46-76-559-1708 (S.K.)
}

Received: 8 January 2020; Accepted: 5 February 2020; Published: 10 February 2020

\begin{abstract}
The biodiversity of the Mediterranean Sea is rapidly changing due to anthropogenic activity and the recent increase of seawater temperature. Citizen science is escalating as an important contributor in the inventory of rare and data-limited species. In this study, we present several records of five data-limited native fish species from the eastern Mediterranean Sea: Alectis alexandrina (Geoffroy Saint-Hilaire, 1817), Ranzania laevis (Pennant, 1776), Dalatias licha (Bonnaterre, 1788), Lophotus lacepede (Giorna, 1809), and Sudis hyalina (Rafinesque, 1810). All of the records were collected by a participatory process involving fishers and validated by associated taxonomic experts of the citizen science programme "Is it Alien to you? Share it!!!". This study fills an important gap for the distribution of the reported species and signifies the important role of citizen participation as a tool for extending marine biodiversity knowledge and fisheries management in an area with several gaps of knowledge on targeted and non-targeted species.
\end{abstract}

Keywords: Alexandria pompano; Slender sunfish; Kitefin shark; Crested oarfish; Barracudina; eastern Mediterranean Sea

\section{Introduction}

The Mediterranean Sea is facing several unprecedented anthropic pressures (e.g. pollution, habitat destruction, and geographical reshuffling of species) [1,2]. Along with climate change, species community shifts are regularly observed, leading to the tropicalization of the Mediterranean Sea $[3,4]$. Projections have indicated that at least $25 \%$ of the Mediterranean continental shelf might experience a total modification of species assemblages by the end of the $21^{\text {st }}$ century [5]. Major gaps exist regarding deep species assemblages [6], particularly rare and data-limited species. This is mainly attributed to fragmented research, scarcity of observations, less fishing pressure, and practical difficulties in monitoring deeper waters.

Historically, the low economic value of non-targeted species has led to less data and a lack of vulnerability assessments. Some progress has been made in recent years to develop methods on status and risk assessments [7], such as mixed fisheries [8] and policy requirements $[9,10]$. Thus, the methodology has been developed, including time-series catch data [11], life history aspects [12], 
and size structure [13]. Another aspect is the willingness by citizens to pay for climate adaptation and fisheries resources, as shown by Tulone et al. [14].

Citizen science is emerging as a key component for the exploration of marine biodiversity, being widely acknowledged by scientists, policy-makers, and conservationists, due to its capacity to address conservation issues that are related to rare species, climate change, and coastal systems [15-17]. Currently, there is an increasing number of citizen science efforts in the Mediterranean Sea $t$ focused on various topics that are related to the marine environment [18-20]. This provides high potential for addressing data gaps related to least studied species. However, citizen science data should be carefully treated, since they often incorporate taxonomic uncertainties and misidentification due to photographic identification [21,22].

Here, we report several records of five data-limited fish species in the eastern Mediterranean Sea and highlight the use of citizen science as an emerging scientific tool for increasing our understanding on species distributions and contributing to fisheries management in the Mediterranean Sea. In addition, we used current published literature to highlight and give a quantitative aspect of current and historical knowledge of the studied species distribution in the eastern Mediterranean Sea (Supplementary Table S1).

\section{Materials and Methods}

The citizen-science programme “Is it Alien to you? Share it!!!" was initially launched in May 2016 by the Environmental Organisation iSea, with the aim of recording information on the occurrence, distribution, and expansion of marine non-native and rare species in Greece. An online easy-to-upload data repository was generated for citizens that allowed for records with pictures to be tracked. In addition, a Facebook group was created and all of the uploaded pictures to the group were automatically uploaded to the same data repository. At the time, this manuscript was written, this project's Facebook group numbers $>10,000$ members, among which approximately 5000 are actively engaged. Each observer is requested to provide for each photo information on species size in total length (TL in cm.) and/or wet weight (WW; in g.). It is also requested to provide more information regarding the depth $(\mathrm{D}$; in meters), the number of individuals $(\mathrm{N})$, the location in latitude and longitude (LAT: LON), the date (DD: MM: YYYY), and the type of observation, as: underwater observation (UW), stranded (S) (i.e. found deceased on shore). Trained observers with silhouettes measured all of the individuals that were categorized as UW. If fishing gear/practice was provided, each observation was categorized following the FAO classification: longline (LL), bottom longline (bLL), surface longline (sLL), harpoons (HAR), and handlines and pole-lines that are hand-operated (LHP) (Figure 1, Table 1). All of the records are pre-scanned for quality and sent out for external evaluation to taxonomic experts prior to the inclusion in the final dataset of iSea. Only confirmed observations are recorded in the dataset, either through photo-identification or in-situ validation. 


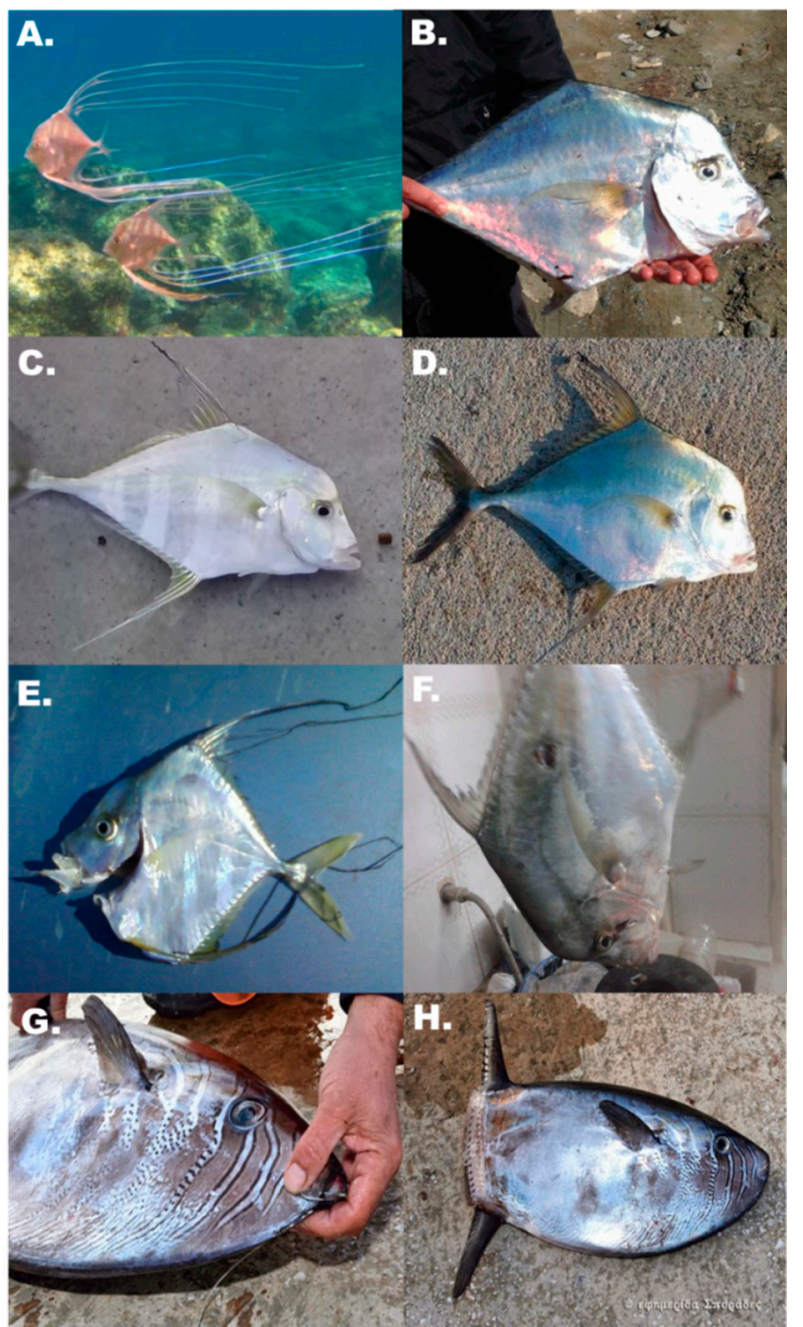

Figure 1. (A,B): Alectis alexandrina juvenile sighted in Protaras, Cyprus; (B,C): Alectis alexandrina adults caught in Zygi and Limassol port (Cyprus) respectively; (D): Alectis alexandrina adult captured in the harbour of Kos Island, Greece; (E): Alectis alexandrina juvenile sighted in Zygi, Cyprus; (F): Alectis alexandrina captured by spearfishing in Akrotiri Bay, Cyprus; $(\mathbf{G}, \mathbf{H})$ : Ranzania laevis individual captured with surface longline in Psathoura Island, Greece.

Table 1. Records of five rare species in the eastern Mediterranean Sea with information on number of individuals $(\mathrm{N})$, depth (m.), total length (cm.), area, coordinates (lat: lon) in decimal degrees and type of observation (underwater, UW; shore fishing, SF; spearfishing,; demersal longline, LL; Otter bottom trawl OTB).

\begin{tabular}{|c|c|c|c|c|c|c|c|}
\hline n & Species & $\begin{array}{c}\mathrm{N} \\
\text { Individuals }\end{array}$ & Depth & TL & Area & Coordinates & $\begin{array}{c}\text { Type of } \\
\text { Observation }\end{array}$ \\
\hline 1 & A. alexandrina & 2 & N/A & 10 & Protaras, Cyprus & $\begin{array}{c}35^{\circ} 00^{\prime} 48.6^{\prime \prime} \mathrm{N} \\
34^{\circ} 02^{\prime} 14.6^{\prime \prime} \mathrm{E}\end{array}$ & UW \\
\hline 2 & A. alexandrina & 1 & N/A & 45 & Zygi, Cyprus & $\begin{array}{l}34^{\circ} 43^{\prime} 35.3^{\prime \prime} \mathrm{N}, \\
33^{\circ} 20^{\prime} 15.0^{\prime \prime} \mathrm{E}\end{array}$ & SF \\
\hline 3 & A. alexandrina & 1 & 5 & 45 & $\begin{array}{l}\text { Old port of Limassol, } \\
\text { Cyprus }\end{array}$ & $\begin{array}{l}34^{\circ} 40^{\prime} 13.8^{\prime \prime} \mathrm{N} \\
33^{\circ} 02^{\prime} 34.8^{\prime \prime} \mathrm{E}\end{array}$ & SF \\
\hline 4 & A. alexandrina & 1 & N/A & 50 & $\begin{array}{c}\text { Port of Kos Island, } \\
\text { Greece }\end{array}$ & $\begin{array}{l}36^{\circ} 53^{\prime} 43.8^{\prime \prime} \mathrm{N} \\
27^{\circ} 17^{\prime} 19.0^{\prime \prime} \mathrm{E}\end{array}$ & SF \\
\hline 5 & A. alexandrina & 1 & N/A & 22 & Zygi, Cyprus & $\begin{array}{l}34^{\circ} 43^{\prime} 41.5^{\prime \prime} \mathrm{N} \\
33^{\circ} 20^{\prime} 25.8^{\prime \prime} \mathrm{E}\end{array}$ & S \\
\hline 6 & A. alexandrina & 1 & 5 & 60 & Akrotiri Bay, Cyprus & $\begin{array}{c}34^{\circ} 33^{\prime} 20.2^{\prime \prime} \mathrm{N} \\
33^{\circ} 00^{\prime} 59.8^{\prime \prime} \mathrm{E}\end{array}$ & SF \\
\hline 7 & A. alexandrina & 1 & 4 & 15 & Ayia Napa, Cyprus & $\begin{array}{l}34^{\circ} 58^{\prime} 53.0^{\prime \prime} \mathrm{N} \\
34^{\circ} 00^{\prime} 17.9^{\prime \prime} \mathrm{E}\end{array}$ & SF \\
\hline
\end{tabular}


Table 1. Cont.

\begin{tabular}{|c|c|c|c|c|c|c|c|}
\hline $\mathbf{n}$ & Species & $\begin{array}{c}\mathrm{N} \\
\text { Individuals }\end{array}$ & Depth & TL & Area & Coordinates & $\begin{array}{c}\text { Type of } \\
\text { Observation }\end{array}$ \\
\hline 8 & A. alexandrina & 1 & N/A & 45 & Zygi, Cyprus & $\begin{array}{l}34^{\circ} 40^{\prime} 15.7^{\prime \prime} \mathrm{N} \\
33^{\circ} 02^{\prime} 39.4^{\prime \prime} \mathrm{E}\end{array}$ & $S$ \\
\hline 9 & A. alexandrina & 1 & 3,5 & 6,5 & Protaras, Cyprus & $\begin{array}{l}35^{\circ} 00^{\prime} 30.1^{\prime \prime} \mathrm{N} \\
34^{\circ} 03^{\prime} 48.4^{\prime \prime} \mathrm{E}\end{array}$ & UW \\
\hline 10 & R. laevis & 1 & 200 & 53 & $\begin{array}{l}\text { Psathoura island, } \\
\text { Greece }\end{array}$ & $\begin{array}{c}39^{\circ} 26^{\prime} 46.0^{\prime \prime} \mathrm{N}, \\
24^{\circ} 04^{\prime} 46.1^{\prime \prime} \mathrm{E}\end{array}$ & LL \\
\hline 11 & D. licha & 1 & 612 & 150 & Levitha island, Greece & $\begin{array}{l}36^{\circ} 58^{\prime} 23.2^{\prime \prime} \mathrm{N} \\
26^{\circ} 29^{\prime} 11.4^{\prime \prime} \mathrm{E}\end{array}$ & LL \\
\hline 12 & D. licha & 1 & 580 & 150 & Amorgos island, Greece & $\begin{array}{l}36^{\circ} 46^{\prime} 25.7^{\prime \prime} \mathrm{N} \\
26^{\circ} 02^{\prime} 38.0^{\prime \prime} \mathrm{E}\end{array}$ & LL \\
\hline 13 & L. lacepede & 1 & 500 & 160 & $\begin{array}{l}\text { Between Skopelos and } \\
\text { Euboea island, Greece }\end{array}$ & $\begin{array}{l}36^{\circ} 46^{\prime} 25.7^{\prime \prime} \mathrm{N}, \\
23^{\circ} 34^{\prime} 44.0^{\prime \prime} \mathrm{E}\end{array}$ & LL \\
\hline 14 & L. lacepede & 1 & 500 & 140 & $\begin{array}{l}\text { Between Skopelos and } \\
\text { Euboea island, Greece }\end{array}$ & $\begin{array}{l}36^{\circ} 46^{\prime} 25.7^{\prime \prime} \mathrm{N}, \\
23^{\circ} 34^{\prime} 44.0^{\prime \prime} \mathrm{E}\end{array}$ & LL \\
\hline 15 & L. lacepede & 1 & 540 & 60 & $\begin{array}{l}\text { Between Santorini and } \\
\text { Anafi island, Greece }\end{array}$ & $\begin{array}{l}36^{\circ} 22^{\prime} 39.4^{\prime \prime} \mathrm{N} \\
25^{\circ} 35^{\prime} 44.5^{\prime \prime} \mathrm{E}\end{array}$ & LL \\
\hline 16 & L. lacepede & 1 & 300 & 100 & $\begin{array}{l}\text { Chalkidiki Peninsula, } \\
\text { Greece }\end{array}$ & $\begin{array}{l}39^{\circ} 44^{\prime} 10.7^{\prime \prime} \mathrm{N}, \\
23^{\circ} 22^{\prime} 56.6^{\prime \prime} \mathrm{E}\end{array}$ & LL \\
\hline 17 & L. lacepede & 1 & 540 & 140 & Crete island, Greece & $\begin{array}{l}35^{\circ} 34^{\prime} 58.0^{\prime \prime} \mathrm{N}, \\
23^{\circ} 29^{\prime} 29.1^{\prime \prime} \mathrm{E}\end{array}$ & LL \\
\hline 18 & L. lacepede & 1 & 40 & 25 & Rhodes island, Greece & $\begin{array}{l}36^{\circ} 27^{\prime} 21.6^{\prime \prime} \mathrm{N}, \\
28^{\circ} 13^{\prime} 05.5^{\prime \prime} \mathrm{E}\end{array}$ & BS \\
\hline 19 & S. hyalina & 1 & 700 & N/A & $\begin{array}{l}\text { Kastellorizo island, } \\
\text { Greece }\end{array}$ & $\begin{array}{l}35^{\circ} 51^{\prime} 41.4^{\prime \prime} \mathrm{N}, \\
30^{\circ} 06^{\prime} 32.0^{\prime \prime} \mathrm{E}\end{array}$ & LL \\
\hline 20 & S. hyalina & 1 & 200 & 30 & Akrotiri Bay, Cyprus & $\begin{array}{l}34^{\circ} 32^{\prime} 46.0^{\prime \prime} \mathrm{N} \\
32^{\circ} 56^{\prime} 56.4^{\prime \prime} \mathrm{E}\end{array}$ & SF \\
\hline 21 & S. hyalina & 1 & 100 & N/A & Crete island, Greece & $\begin{array}{l}35^{\circ} 31^{\prime} 20.8^{\prime \prime} \mathrm{N}, \\
24^{\circ} 00^{\prime} 55.5^{\prime \prime} \mathrm{E}\end{array}$ & BS \\
\hline 22 & S. hyalina & 1 & 300 & 40 & Morfou Gulf, Cyprus & $\begin{array}{l}35^{\circ} 13^{\prime} 43.4^{\prime \prime} \mathrm{N}, \\
32^{\circ} 52^{\prime} 01.1^{\prime \prime} \mathrm{E}\end{array}$ & BS \\
\hline 23 & S. hyalina & 1 & 400 & N/A & Crete island, Greece & $\begin{array}{l}34^{\circ} 54^{\prime} 55.1^{\prime \prime} \mathrm{N}, \\
24^{\circ} 54^{\prime} 50.6^{\prime \prime} \mathrm{E}\end{array}$ & BS \\
\hline 24 & S. hyalina & 1 & 100 & $\mathrm{~N} / \mathrm{A}$ & Saronikos Gulf, Athens & $\begin{array}{l}37^{\circ} 50^{\prime} 12.0^{\prime \prime} \mathrm{N}, \\
23^{\circ} 18^{\prime} 50.7^{\prime \prime} \mathrm{E}\end{array}$ & BS \\
\hline 25 & S. hyalina & 1 & 612 & 35 & Levitha island, Greece & $\begin{array}{l}37^{\circ} 00^{\prime} 02.9^{\prime \prime} \mathrm{N}, \\
26^{\circ} 27^{\prime} 32.6^{\prime \prime} \mathrm{E}\end{array}$ & LL \\
\hline
\end{tabular}

All of the data used in this study has been uploaded to an electronic repository (https://wp.me/ P94Vaj-1Mm).

\section{Results}

\subsection{Alectis Alexandrina}

On 20th November 2012, two juvenile individuals $(\approx 10 \mathrm{~cm}$ TL) were sighted and photographed

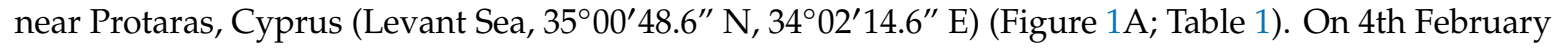
2015, an individual with a TL of $45 \mathrm{~cm}$ was caught by a recreational fisherman at Zygi, Cyprus (Levant Sea, $34^{\circ} 43^{\prime} 35.3^{\prime \prime} \mathrm{N}, 33^{\circ} 20^{\prime} 15.0^{\prime \prime} \mathrm{E}$ ), while a second individual, approximately of the same size, was caught on 30th May 2015 in the old port of Limassol (Levant Sea, 34 $40^{\prime} 13.8^{\prime \prime} \mathrm{N}, 33^{\circ} 02^{\prime} 34.8^{\prime \prime} \mathrm{E}$ ) (Figure 1B,C). On July 2016, a single individual with a TL of $\approx 50 \mathrm{~cm}$ and $1100 \mathrm{~g}$ in weight was caught by a recreational fisherman at the port of Kos Island (Aegean Sea; $36^{\circ} 53^{\prime} 43.8^{\prime \prime} \mathrm{N}, 27^{\circ} 17^{\prime} 19.0^{\prime \prime} \mathrm{E}$; Figure 1D). On 16th March 2017, a juvenile individual ( $\approx 22 \mathrm{~cm}$ TL for $100 \mathrm{~g}$ ) was found stranded near to Zygi village, Cyprus (Levant Sea, $34^{\circ} 43^{\prime} 41.5^{\prime \prime} \mathrm{N}, 33^{\circ} 20^{\prime} 25.8^{\prime \prime} \mathrm{E}$ ) (Figure 1E). On 11th October 2017, an individual $(\approx 60 \mathrm{~cm}$ TL) was captured by spearfishing at a depth of $5 \mathrm{~m}$ at Akrotiri Bay in

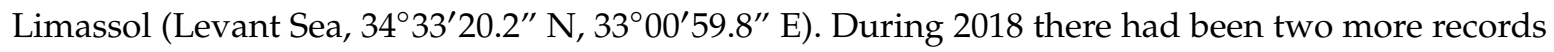
that were collected on 9th of October an individual of $\approx 15 \mathrm{~cm}$ TL by a spear fisher and another individual $\approx 6.5 \mathrm{~cm}$ TL was photographed by a diver; both occurrences were in Cyprus Ayia Napa,

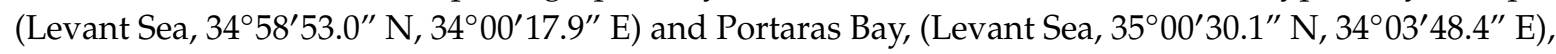


accordingly (Table 1). Finally, there has been another stranded individual of $45 \mathrm{~cm} \mathrm{TL}$, in Zygi, Cyprus

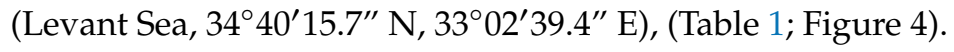

\subsection{Ranzania Laevis}

On $21^{\text {st }}$ December 2014, an individual of $R$. laevis was captured with a surface longline near Psathoura Island in North Aegean Sea ( $\left.39^{\circ} 26^{\prime} 46.0^{\prime \prime} \mathrm{N}, 24^{\circ} 04^{\prime} 46.1^{\prime \prime} \mathrm{E}\right)$ at a depth of approximately $200 \mathrm{~m}$ and landed at Skopelos Island (Figure 1G, H). The specimen was $53 \mathrm{~cm}$ in TL. The fisherman and a local journalist contacted the local authorities, which identified the species as "Propela", the common Greek name for Mola mola. On $29^{\text {th }}$ of July 2017 the journalist contacted iSea, in the context of the citizen science project "Is it Alien to you? Share it!!!" for sharing a log of rare species observations from Skopelos Island. Among the observations, the record of $R$. laevis was found and all of the available information was collected.

\subsection{Dalatias Licha}

On $5^{\text {th }}$ November 2016 , a single male individual of $D$. licha $(\approx 150 \mathrm{~cm} \mathrm{TL})$ was caught by a demersal longline at a depth of $580 \mathrm{~m}$ off Amorgos Island (Aegean Sea, $36^{\circ} 46^{\prime} 25.7^{\prime \prime} \mathrm{N}, 26^{\circ} 02^{\prime} 38.0^{\prime \prime} \mathrm{E}$ ) (Figure 2A). On $29^{\text {th }}$ August 2019 an individual was caught off Levithas island at a depth of $612 \mathrm{~m}$ in depth by a demersal longline over muddy substrate (Aegean Sea; 36 58 $23.2^{\prime \prime}$ N, $26^{\circ} 29^{\prime} 11.4^{\prime \prime}$ E) (Table 1; Figure 4).

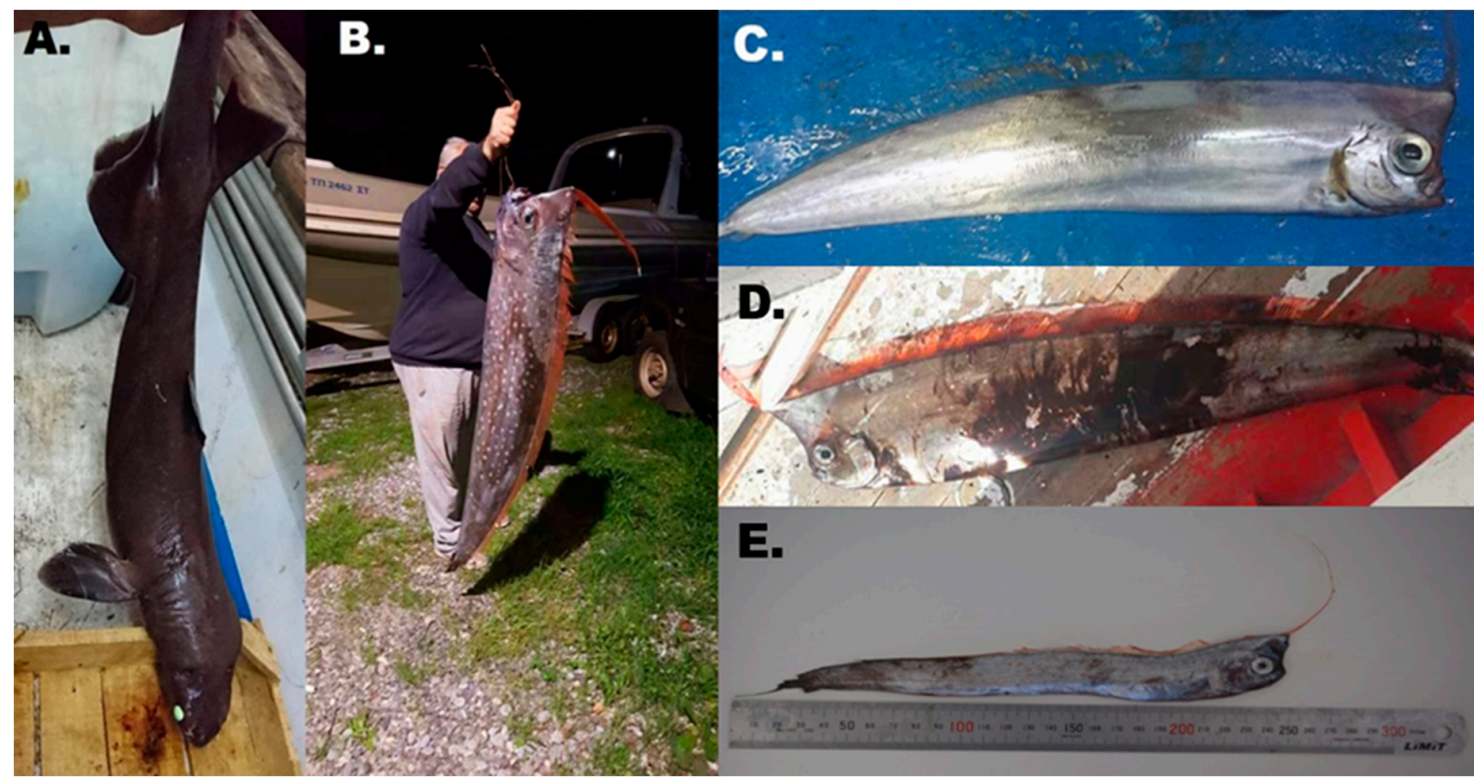

Figure 2. (A): Male Dalatias licha caught with demersal longlines off Amorgos Island, Greece; (B): $L$. lacepede caught with demersal longlines between Skopelos and Euboea Islands, Greece; (C): L. lacepede caught with demersal longlines between Santorini and Anafi Islands, Greece; and, (D): L. lacepede caught off the Coast of Chalkidiki Peninsula, Greece; (E): L. lacepede, Rhodes Island, Greece.

\subsection{Lophotus Lacepede}

Demersal longlines set at $500 \mathrm{~m}$ deep bottoms between Skopelos and Euboea Islands (Aegean Sea, $36.7738^{\circ} \mathrm{N}, 23.5789^{\circ} \mathrm{E}$ ) allowed for the capture of a large individual ( $\left.\approx 160 \mathrm{~cm} \mathrm{TL}, 10 \mathrm{~kg} \mathrm{WW}\right)$ (Figure 2B) on $3^{\text {rd }}$ March 2017. A few days later, on $9^{\text {th }}$ March 2017, a slightly smaller individual (approximately $140 \mathrm{~cm}$ in TL and $8 \mathrm{~kg}$ in WW) was collected from the same area while using the same fishing gear. A third, distinctly smaller individual ( $\approx 60 \mathrm{~cm}$ in TL) (Figure $2 \mathrm{C}$ ) was captured by demersal longlines at a depth of $540 \mathrm{~m}$ between Santorini and Anafi Islands (Aegean Sea; $36.3776^{\circ} \mathrm{N}$, $25.5957^{\circ} \mathrm{E}$ ). Lastly, on $6^{\text {th }}$ October 2017, a fourth large individual (approximately $100 \mathrm{~cm}$ in TL and $6 \mathrm{~kg}$ in WW) (Figure 2D) was captured by a longline targeting swordfish off the coast of Chalkidiki Peninsula 
towards Sporades Islands (North Aegean Sea; $39^{\circ} 44^{\prime} 10.7^{\prime \prime} \mathrm{N}, 23^{\circ} 22^{\prime} 56.6^{\prime \prime}$ E) at a depth of approximately $300 \mathrm{~m}$. On September 12, 2017 an individual of $\approx 25 \mathrm{~cm}$ in TL was caught outside Rhodes Island, Greece ( $\left(36^{\circ} 27^{\prime} 21.6^{\prime \prime} N\right.$ N $28^{\circ} 13^{\prime} 05.5^{\prime \prime}$ E) (Figure 2E). On $1^{\text {st }}$ of November 2018 , an individual of $\approx 140 \mathrm{~cm}$ in TL was caught by a professional fisher with a demersal longline at a depth of $540 \mathrm{~m}$ (Cretan Sea, $23^{\circ} 29^{\prime} 29.1^{\prime \prime} \mathrm{N}, 35^{\circ} 34^{\prime} 58.0^{\prime \prime}$ E) (Figure 4).

\subsection{Sudis Hyalina}

On 1st July of 2014, an individual was caught at $100 \mathrm{~m}$ in depth by demersal longline of a recreational fisher, off Crete Island (Aegean Sea, $35^{\circ} 31^{\prime} 20.8^{\prime \prime} \mathrm{N}, 24^{\circ} 00^{\prime} 55.5^{\prime \prime}$ E). On $6^{\text {th }}$ November 2016 an individual was caught by demersal longline approximately 30 miles south-east from Kastellorizo Island and at approximately $700 \mathrm{~m}$ in depth (Aegean Sea; $35^{\circ} 51^{\prime} 41.4^{\prime \prime} \mathrm{N}, 30^{\circ} 06^{\prime} 32.0^{\prime \prime} \mathrm{E}$ ) (Figure 3A). The specimen was found mutilated by another fish, possibly a scabbardfish (Lepidopus caudatus; Euphrasen, 1788), but features of the head allowed for a uniequivocal identification. On 17th August 2017 , another individual of $S$. hyalina $\left(\approx 30 \mathrm{~cm}\right.$ TL) was captured at Akrotiri, Cyprus $\left(34^{\circ} 32^{\prime} 46.0^{\prime \prime} \mathrm{N}\right.$, $32^{\circ} 56^{\prime} 56.4^{\prime \prime}$ E) by a recreational fisher at an approximate depth of $200 \mathrm{~m}$ (Figure 3B,C). During 2018, another record was added from Morfou in Cyprus; the individual was approximately $40 \mathrm{~cm}$ in TL and it was caught at $300 \mathrm{~m}$ in depth (Levantine Sea, $35^{\circ} 13^{\prime} 43.4^{\prime \prime} \mathrm{N}, 32^{\circ} 52^{\prime} 01.1^{\prime \prime} \mathrm{E}$ ). On 19th May 2019, another individual was caught in $400 \mathrm{~m}$ by shore-based fishing off Crete island (Cretan Sea, $34^{\circ} 54^{\prime} 55.1^{\prime \prime}$ N, $24^{\circ} 54^{\prime} 50.6^{\prime \prime}$ E); on 29th August 2019, an individual was caught off Levithas island at $612 \mathrm{~m}$ in depth with demersal longline over muddy substrate along with a D. licha individual (Aegean Sea, $37^{\circ} 00^{\prime} 02.9^{\prime \prime}$ N, $26^{\circ} 27^{\prime} 32.6^{\prime \prime}$ E), (Table 1; Figure 4). The latest record was on 17th September 2019, where another individual of $\approx 20 \mathrm{~cm}$ in TL was caught by demersal longline at $100 \mathrm{~m}$ in depth at Saronikos Gulf

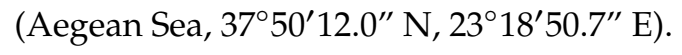

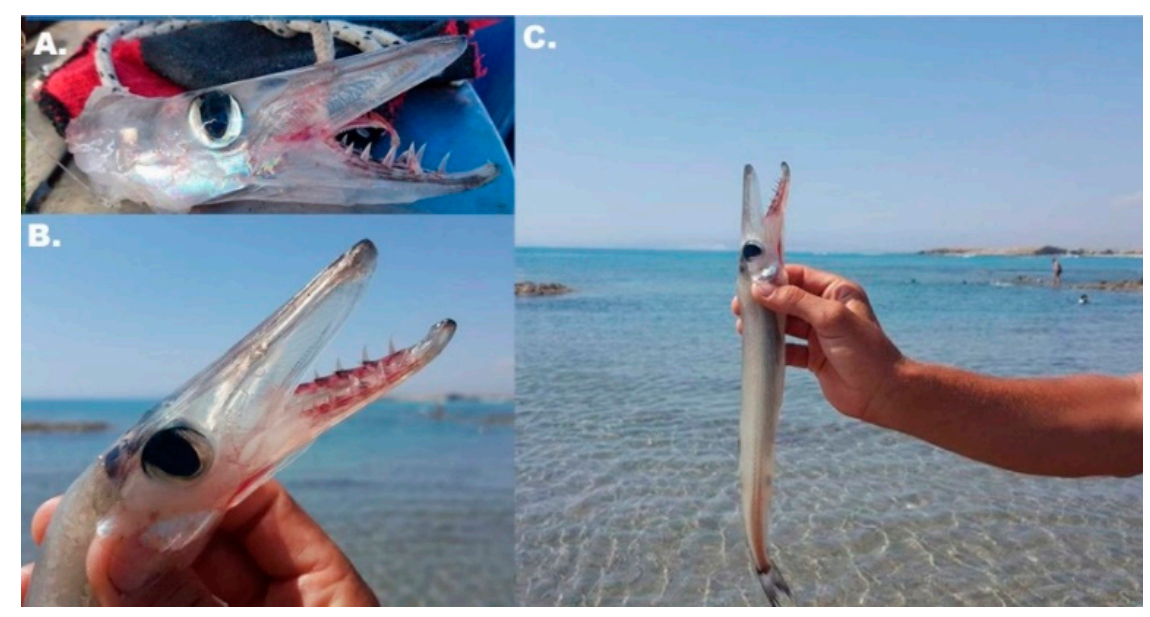

Figure 3. (A): Head of Sudis hyalina collected from demersal longlines off Kastellorizo Island, Greece; (B) individual captured in Akrotiri Bay, Cyprus; and, (C): individual captured in Chalkidiki Peninsula, Greece. 

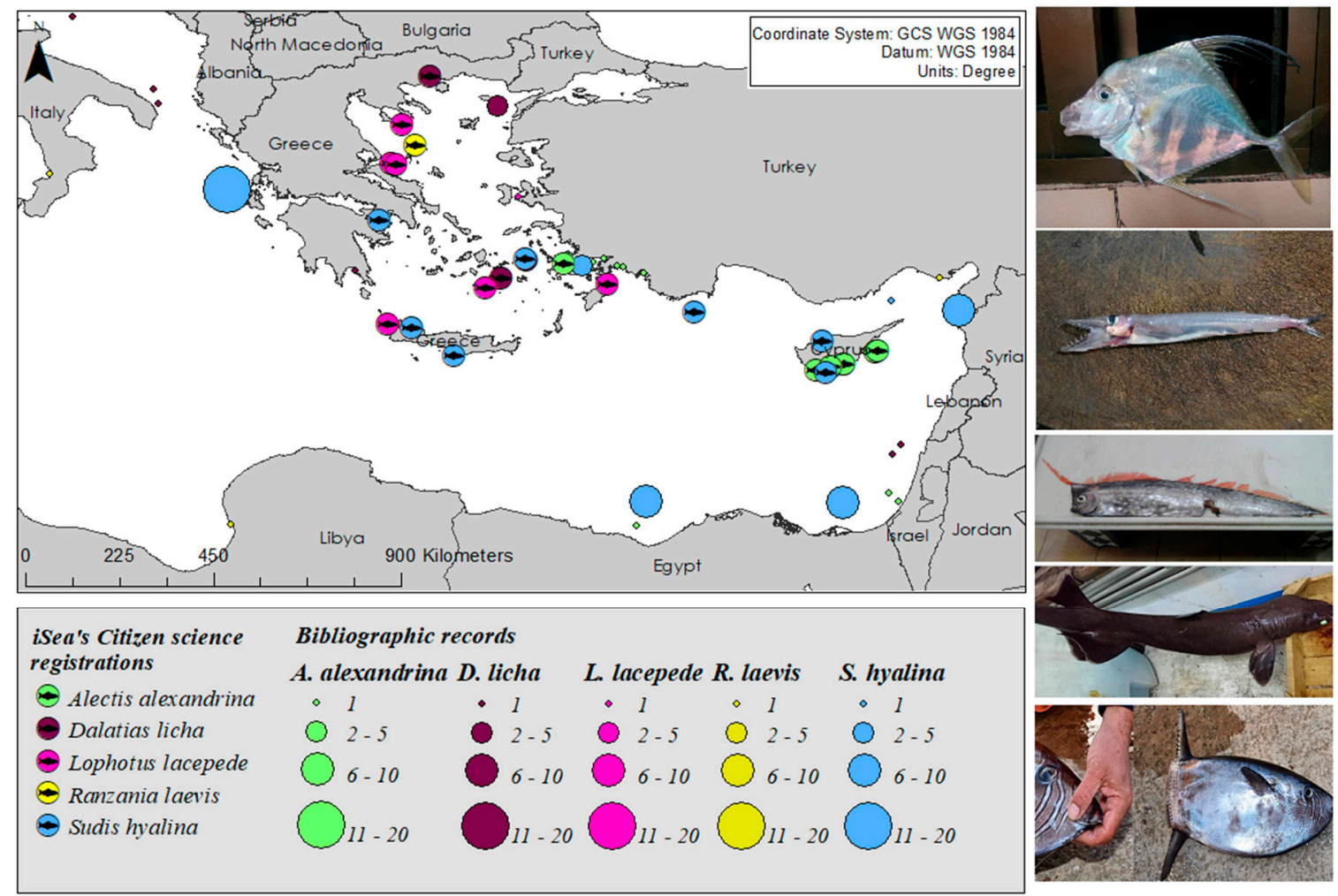

Figure 4. Geographic density dependent bubble plot on five uncommon data-limited species (Alectis alexandrina, Dalatias licha, Lophotus lacepede, Ranzania laevis and Sudis hyalina) in the eastern Mediterranean Sea.

We found that, based on current literature (Supplementary Table S1), the reported number of individuals in this study contributed $21.6 \%$ of the reports the species in the eastern Mediterranean Sea and $27.3 \%$ to the total number of reports during the last decade. For some species, the contribution to the total number of reports in the eastern Mediterranean was higher: (a) A. alexandrina contributed $34.4 \%$ of the reports the species in the eastern Mediterranean Sea and 35.7\% to total number of reported species in the eastern Mediterranean Sea during the last decade, (b) R. laevis contributed $11.1 \%$ of the reports of the species in the eastern Mediterranean Sea and 20\% of the reports of the species in the eastern Mediterranean Sea during the last decade, (c) D. licha contributed $18.9 \%$ of the reports of the species in the eastern Mediterranean Sea and $28.6 \%$ of the reports of the species in the eastern Mediterranean Sea during the last decade, (d) L. lacepede contributed $46.1 \%$ of the reports of the species in the eastern Mediterranean Sea and 75\% of the reports of the species in the eastern Mediterranean Sea during the last decade and (e) S. hyalina contributed $11.9 \%$ of the reports of the species in the eastern Mediterranean Sea and 14\% of the reports of the species in the eastern Mediterranean Sea during the last decade.

\section{Discussion}

The present work provides additional information on five uncommon fish species for the Aegean and Levantine Sea. Rare species are often considered to be data-limited. However, spatial and temporal variations in the distribution of rare species might provide relevant signs of climate and environmental change $[23,24]$. Until recently, the scarce communication between researchers and citizens entailed the loss of an important part of available information on these species, while the recent increase in the use of social networks allowed for a closer communication that can result in an increase of records of rare and non-native species [20,25-28]. To date, the project "Is it Alien to you? Share it!!!" has gathered a 
vast amount of information regarding the distribution and establishment of species, including several first records, as well as expansion evidences [20].

Alectis alexandrina is a thermophilic species with a rather sporadic occurrence in the Mediterranean Sea. Fishers state that the species is increasingly caught the last years, being very common in Cyprus and rather sporadic in southern Aegean Sea, despite the few observations from the northeast Mediterranean Sea.

Ranzania laevis commonly known as slender sunfish (Fam. Molidae) is a pelagic-oceanic cosmopolitan species found in tropical and temperate seas and feeding on small fish, planktonic crustaceans, and jellyfish. It is one of the two Molidae species occurring in the Mediterranean Sea; however, reports of $R$. laevis from the eastern basin are scarce. Occasional records from Greece [29], Cyprus and Israel [30], Turkey [31], and Lybia [32] have been reported. Current distribution of R. laevis covers the whole Mediterranean Sea while quantitative information has revealed a rather sporadic occurrence and local peaks of abundance with increased zooplankton biomass [23]. The reported species is the second record from the north Aegean Sea [29].

The remaining three species reported are typical rare deep-water species in the eastern Mediterranean Sea [6]. Recent studies demonstrated the occurrence of these deep-water species, as previously overlooked in the eastern Mediterranean Sea [33,34].

Dalatias licha, commonly known as the kitefin shark, is one of the largest deep-sea sharks occurring in the Mediterranean Sea, being distributed at depths between 200 and $900 \mathrm{~m}$, where it can be considered a top predator. It is although an uncommon species in the western and central part of the basin [35,36], while its presence in the eastern Mediterranean Sea is considered as very scarce [37,38], signifying any reports as highly valuable, also given the conservation status of the Mediterranean population of the species as vulnerable [39].

Lophotus lacepede, commonly known as the crested oarfish, is a large bathypelagic species that is remarkably sporadic in the whole Mediterranean Sea. Similarly, to the majority of deep-sea fish species it is more regularly observed in the western Mediterranean Sea, with only a few records in the eastern part of the basin. Currently, only four published records are known, all being from the Aegean Sea [40]. The observations that are reported in the current work highlight the deep waters between Chalkidiki Peninsula and Evoia Islands as an important area for the species.

Sudis hyalina, which is a rare bathypelagic cosmopolitan fish species, is considered to be regular in the western part of the Mediterranean basin, while only five documented records of the species exist from the eastern Mediterranean basin [41]. In the Aegean Sea only two records of the species have been published [29]. Consequently, the record presented in this study is the third record of the species from the Aegean Sea. Interestingly, the report from Cyprus is the first record of the species from the Cypriot territorial waters, most possibly an overlooked species.

\section{Conclusions}

This study reveals that the contribution of citizen-science accounts for $45.4 \%$ of the total number of the studied species published records and $58.5 \%$ of the total number of published records during the last decade in the eastern Mediterranean Sea. This signifies the important role of citizen-science efforts, both for scientific and public awareness. Nine more records of the reported species have been published since "Is it Alien to you? Share it!!!" was launched [38,42-46], whereas, in this article, we report the occurrence of 26 individuals contributing with $74.2 \%$ during the same period. Of course, it can be hard to determine whether the species density in the region has increased or if the reports were overlooked before pictures of the species were circulated on social media as something rare. Thus, post-hoc interviews with citizens and fishermen who report catches can be used to reconstruct species distributions and densities.

Supplementary Materials: The following are available online at http://www.mdpi.com/2077-1312/8/2/107/s1, Table S1. Up-to-date records of five data-limited species in the eastern Mediterranean Sea. 
Author Contributions: Conceptualization, S.K., I.G., P.K. and R.N.A.S.; methodology, S.K., R.N.A.S.; software, R.N.A.S.; validation, S.K. and R.N.A.S.; formal analysis, S.K. and R.N.A.S.; investigation, S.K.; R.N.A.S., I.G., P.K., J.L., D.B.; resources, S.K.; R.N.A.S., I.G., P.K., J.L., D.B.; data curation, R.N.A.S., S.K.; writing-original draft preparation, S.K.; R.N.A.S., I.G., P.K., J.L., D.B.; writing-review and editing, S.K., R.N.A.S., I.G., P.K., J.L. and D.B.; visualization, S.K., R.N.A.S.; supervision, S.K.; project administration, I.G.; funding acquisition, I.G. All authors have read and agreed to the published version of the manuscript.

Funding: This research was funded by iSea, Environmental Organisation for the preservation of the aquatic ecosystems-“Is it Alien to you? Share it!!!".

Acknowledgments: We are grateful to the fisherman Nikolas Katsillis (Greece) for sharing his pictures and data for three specimens of S. hyalina, L. lacepede and D. licha, Antonis Voutsas (Greece) for sharing his picture and data of L. lacepede, to Werner Wolf (Austria), Pabos Charalambous (Cyprus), Savvas Ioannou (Cyprus), Michalis Ilia (Cyprus) and Antonis Salachoris (Greece) for sharing data and pictures of the A. alexandrina specimens, Angelos Kouriefs (Cyprus) for sharing data and pictures of S. hyalina specimen and Georgios Poulios (Greece) for sharing data and pictures of $R$. laevis and all the other citizen scientists who contributed in gathering the information needed.

Conflicts of Interest: The authors declare no conflict of interest. The funders had no role in the design of the study; in the collection, analyses, or interpretation of data; in the writing of the manuscript, or in the decision to publish the results.

\section{References}

1. Fortibuoni, T.; ldighieri, F.; Giovanardi, O.; Pranovi, F.; Zucchetta, M. Climate impact on Italian fisheries (Mediterranean Sea). Reg. Environ. Chang. 2015, 15, 931-937. [CrossRef]

2. Macías, D.; Castilla-Espino, D.; García-del-Hoyo, J.J.; Navarro, G.; Catalán, I.A.; Renault, L.; Ruiz, J. Consequences of a future climatic scenario for the anchovy fishery in the Alboran Sea (SW Mediterranean): A modeling study. J. Mar. Syst. 2014, 135, 150-159. [CrossRef]

3. Occhipinti-Ambrogi, A. Global change and marine communities: Alien species and climate change. Mar. Pollut. Bull. 2007, 55, 342-352. [CrossRef] [PubMed]

4. Lejeusne, C.; Chevaldonné, P.; Pergent-Martini, C.; Boudouresque, C.F.; Perez, T. Climate change effects on a miniature ocean: The highly diverse, highly impacted Mediterranean Sea. Trends Ecol. Evol. 2010, 25, 250-260. [CrossRef] [PubMed]

5. Lasram, B.R.F.; Guilhaumon, F.; Albouy, C.; Somot, S.; Thuiller, W.; Mouillot, D. The Mediterranean Sea as a 'cul-de-sac' for endemic fishes facing climate change. Glob. Chang. Biol. 2010, 16, 3233-3245. [CrossRef]

6. Danovaro, R.; Company, J.B.; Corinaldesi, C.; D’Onghia, G.; Galil, B.; Gambi, C.; Gooday, A.J.; Lampadariou, N.; Luna, G.M.; Morigi, C.; et al. Deep-sea biodiversity in the Mediterranean Sea: The known, the unknown, and the unknowable. PLoS ONE 2010, 5, e11832. [CrossRef]

7. Thorson, J.T.; Kell, L.T.; De Oliveira, J.A.A.; Sampson, D.B.; Punt, A.E. Development, testing, and evaluation of data-poor assessment and fisheries management methods. Fish. Res. 2015, 171, 1-200. [CrossRef]

8. Ford, R.B.; Galland, A.; Clark, M.R.; Crozier, P.; Duffy, C.A.J.; Dunn, M.R.; Francis, M.P.; Wells, R. Qualitative (Level 1) Risk Assessment of the Impact of Commercial Fishing on New Zealand Chondrichthyans; New Zealand Aquatic Environment and Biodiversity Report; Ministry for Primary Industries: Wellington, New Zealand, 2015; Volume 157, 111p.

9. Hobday, A.J.; Smith, A.D.M.; Stobutzki, I.C.; Bulman, C.; Daley, R.; Dambacher, J.M.; Deng, R.A.; Dowdneya, J.; Fullera, M.; Furlania, D.; et al. Ecological risk assessment for the effects of fishing. Fish. Res. 2011, 108, 372-384. [CrossRef]

10. Berkson, J.; Barbieri, L.; Cadrin, S.; Cass-Calay, S.; Crone, P.; Dorn, P.; Friess, C.; Kobayashi, D.; Miller, T.J.; Patrick, W.S.; et al. Calculating Acceptable Biological Catch for Stocks That Have Reliable Catch Data Only (Only Reliable Catch Stocks-ORCS); NMFS-SEFSC-616; NOAA Technical Memorandum: Miami, FL, USA, 2011; 56p.

11. Zhou, S.; Punt, A.E.; Ye, Y.; Ellis, N.; Dichmont, C.M.; Haddon, M.; Smith, D.C.; Smith, A.D.M. Estimating stock depletion level from patterns of catch history. Fish Fish. 2017, 18, 742-751. [CrossRef]

12. Dick, E.J.; MacCall, A.D. Depletion-based stock reduction analysis: A catch-based method for determining sustainable yields for data-poor fish stocks. Fish. Res. 2011, 110, 331-341. [CrossRef]

13. Hordyk, A.; Ono, K.; Sainsbury, K.; Loneragan, N.; Prince, J. Some explorations of the life history ratios to describe length composition, spawning-per-recruit, and the spawning potential ratio. ICES J. Mar. Sci. 2015, 72, 204-216. [CrossRef] 
14. Tulone, A.; Crescimanno, M.; Vrontis, D.; Galati, A. Are coastal communities able to pay for the protection of fish resources impacted by climate change? Fish. Res. 2020, 221, 105374. [CrossRef]

15. Thiel, M.; Penna-Díaz, M.A.; Luna-Jorquera, G.; Salas, S.; Sellanes, J.; Stotz, W. Citizen scientists and marine research: Volunteer participants, their contributions, and projection for the future. Oceanogr. Mar. Biol. Annu. Rev. 2014, 52, 257-314. [CrossRef]

16. Theobald, E.J.; Ettinger, A.K.; Burgess, H.K.; DeBey, L.B.; Schmidt, N.R.; Froehlich, H.E.; Parrish, J.K. Global change and local solutions: Tapping the unrealized potential of citizen science for biodiversity research. Biol. Conserv. 2015, 181, 236-244. [CrossRef]

17. Cousins, J.A.; Huxham, M.; Winton, D. Using citizen science to address conservation issues related to climate change and coastal systems. In Science for Coastal and Marine Conservation; Cigliano, J.A., Ballard, J.A., Eds.; Routledge: London, UK, 2017; p. 20.

18. Gerovasileiou, V.; Dailianis, T.; Panteri, E.; Michalakis, N.; Gatti, G.; Sini, M.; Dimitriadis, C.; Issaris, Y.; Salomidi, M.; Filiopoulou, I.; et al. CIGESMED for divers: Establishing a citizen science initiative for the mapping and monitoring of coralligenous assemblages in the Mediterranean Sea. Biodiver. Data J. 2016, 4, e8692. [CrossRef]

19. Barash, A.; Salingre, S.; Grosmark, Y.; Rothman, S.; Stoilas, V.S.; Maximiadi, M.; Tuncer, S.; Lapinski, M.; Nuez, I.; Bakiu, R.; et al. The MECO project (Mediterranean Elasmobranch Citizen Observations): Creating a large-scale database of elasmobranchs observations using social media. In Proceedings of the 22nd Annual European Elasmobranch Association Meeting, Peniche, Portugal, 12-14 October 2018.

20. Giovos, I.; Kleitou, P.; Poursanidis, D.; Batjakas, I.; Bernardi, G.; Crocetta, F.; Doumpas, N.; Kalogirou, S.; Kampouris, T.E.; Keramidas, I.; et al. Citizen-science for monitoring marine invasions and stimulating public engagement: A case project from the eastern Mediterranean. Biol. Invasions 2019, 21, 3707-3721. [CrossRef]

21. Marshall, A.D.; Pierce, S.J. The use and abuse of photographic identification in sharks and rays. J. Fish. Biol. 2012, 80, 1361-1379. [CrossRef]

22. Katsanevakis, S.; Moustakas, A. Uncertainty in Marine Invasion Science. Front. Mar. Sci. 2018, 5, 38. [CrossRef]

23. Dulčić, J.; Beg Paklar, G.; Grbec, B.; Morović, M.; Matić, E.; Lipej, L. On the occurrence of the ocean sunfish Mola mola and slender sunfish Ranzania laevis in the Adriatic Sea. J. Mar. Biol. Assoc. UK 2007, 87, 789-796. [CrossRef]

24. Caballero-Alfonso, A.; Ganzedo-López, U.; Díez-Díez, G.; Castro, J. New record of Ocythoe tuberculata (Cephalopoda: Ocythoidae) in the north-east Atlantic related to sea warming. Mar. Biodivers. Rec. 2009, 2, e79. [CrossRef]

25. Andaloro, F.; Castriota, L.; Falautano, M.; Azzurro, E.; Deidun, A.; Fenech-Farrugia, A. Public feedback on early warning initiatives undertaken for hazardous non-indigenous species: The case of Lagocephalus sceleratus from Italian and Maltese waters. Manag. Biol. Invasion 2016, 7, 313-319. [CrossRef]

26. Kletou, D.; Hall-Spencer, J.M.; Kleitou, P. A lionfish (Pterois miles) invasion has begun in the Mediterranean Sea. Mar. Biodivers. Rec. 2016, 9, e46. [CrossRef]

27. Bariche, M.; Azzurro, E. Enhancing Early Detection through Social Networks: A Facebook Experiment; Rapports et Proces-Verbaux Reunions Commission International Mer Mediterranee; Reunions Commission International: Monaco, 2016; Volume 41, p. 413.

28. Langeneck, J.; Marcelli, M.; Bariche, M.; Azzurro, E. Social networks allow early detection of non indigenous species: First record of the red drum Sciaenops ocellatus (Actinopterygii: Perciformes: Sciaenidae) in Italian waters. Acta Adriat. 2017, 58, 365-370. [CrossRef]

29. Papaconstantinou, C. Fauna Graeciae. An Updated Checklist of the Fishes in the Hellenic Seas; Monographs on Marine Sciences, 7; HCMR: Athens, Greece, 2014; p. 340.

30. Tortonese, E. Molidae. In Fishes of the North-Eastern Atlantic and the Mediterranean; Whitehead, P.J.P., Bauchot, M.-L., Hureau, J.-C., Nielsen, J., Tortonese, E., Eds.; UNESCO: Paris, France, 1986; pp. 1348-1350.

31. Bilecenoglu, M.; Taskavak, E.; Mater, S.; Kaya, M. Checklist of the marine fishes of Turkey. Zootaxa 2002, 113, 1-194. [CrossRef]

32. Elbaraasi, H.; Elsalini, O. Occurrence of slender sunfish Ranzania laevis Pennant, 1776, (Molidae) in the eastern part of the Libyan coast (southern Mediterranean). Turk J. Fish Aquat. Sci. 2010, 10, 549-550. [CrossRef]

33. Goren, M.; Galil, B.S. A checklist of the deep sea fishes of the Levant Sea, Mediterranean Sea. Zootaxa 2015, 3994, 507-530. [CrossRef] 
34. Farrag, M.M.S. Deep-sea ichthyofauna from Eastern Mediterranean Sea, Egypt: Update and new records. Egypt. J. Aquat. Res. 2016, 42, 479-489. [CrossRef]

35. Ragonese, S.; Vitale, S.; Dimech, M.; Mazzola, S. Abundances of demersal sharks and chimaera from 1994-2009 scientific surveys in the central Mediterranean Sea. PLoS ONE 2013, 8. [CrossRef]

36. Navarro, J.; López, L.; Coll, M.; Barría, C.; Saez-Liante, R. Short- and long-term importance of small sharks in the diet of the rare deep-sea shark Dalatias licha. Mar. Biol. 2014, 161, 1697-1707. [CrossRef]

37. Corsini-Foka, M. Uncommon fished from Rhodes and nearby marine region (SE Aegean Sea, Greece). J. Biol. Res. Thessaloniki 2009, 12, 125-133.

38. Ergüden, D.; Çekic, M.; Alagoz Ergüden, S.; Altun, A.; Uygur, N. Occurrence of adult female Kitefin shark Dalatias licha (Bonnaterre, 1788) in Iskenderun Bay (Eastern Mediterranean, Turkey). Commagene J. Biol. 2017, 1, 60-62. [CrossRef]

39. Walls, R.H.L.; Guallart, J. Dalatias licha; The IUCN Red List of Threatened Species 2016: E.T6229A16527825. IUCN, 2016. Available online: http://www.iucnredlist.org/details/6229/16527825 (accessed on 10 February 2020).

40. Minos, G.; Karidas, T.; Economidis, P.S. Range extension for crested oarfish Lophotus lacepede Giorna, 1809 in the waters of the northern Aegean Sea, Greece. Acta Adriat. 2015, 56, 283-290.

41. Türker, D.; Kara, A.; Bal, H.; Tünay, Ö.K. Occurrence of rare deep-water fish Sudis hyalina Rafinesque, 1810 (Paralepididae) in Gökova Bay, Aegean Sea of Turkey. J. Appl. Ichthyol. 2017, 33, 535-538. [CrossRef]

42. Ceyhan, T.; Akyol, O. Additional record of Alectis alexandrina (Carangidae) from the north-western Levantine Sea (Fethiye, Turkey). Ann. Ser. Hist. Nat. 2016, 26, 221-223. [CrossRef]

43. Goren, M.; Galil, B.S.; Diamant, A.; Stern, N.; Levitt-Barmats, Y. Invading up the food web? Invasive fish in the southeastern Mediterranean Sea. Mar. Biol. 2016, 163, 180. [CrossRef]

44. Chatzispyrou, A.; Aroni, M.; Lefkaditou, E.; Kapiris, K.; Giovos, I.; Anastasopoulou, A. Some Biological Information on a Female Kitefin Shark, Dalatias licha (Bonnaterre, 1788) Stranded in the Laconikos Gulf of Greece (SE Ionian Sea). Turk. J. Fish. Aquat. Sci. 2019, 19, 1069-1072. [CrossRef]

45. Yapici, S. New and additional records of rare fish species from the Anatolian coasts of Turkey. Mugla J. Sci. Technol. 2019, 5, 13-15. [CrossRef]

46. Ergüden, D.; Gürlek, M.; Ergüden, S.A.; Ayas, D.; Altun, A. Presence of Ranzania laevis (Pennant, 1776) in Iskenderun Bay, Turkey. Thalassas Int. J. Mar. Sci. 2019. [CrossRef] 